\title{
Short-Term Results After Single-Dose Intravitreal Bevacizumab Treatment for Macular Edema Secondary to Central and Branch Retinal Vein Occlusions
}

\author{
Taha Ayyıldız, ${ }^{1}$ Ayşe Yeşim Aydın Oral, ${ }^{2}$ Ümit Çallı, ${ }^{2}$ Osman Şalkacı, ${ }^{2}$ \\ Baran Kandemir, ${ }^{2}$ Yusuf Özertürk ${ }^{2}$
}

\author{
'Department of Ophthalmology, \\ Haydarpaşa Numune Training and \\ Research Hospital, İstanbul, Turkey \\ ${ }^{2}$ Department of Ophthalmology, \\ Kartal Dr. Lütfi Kırdar Training and \\ Research Hospital, Istanbul, Turkey \\ Submitted: 17.11.2015 \\ Accepted: 23.05 .2017 \\ Correspondence: Taha Ayyıldız \\ Orhantepe Mah., Şehit Astsubay \\ Serkan Aktepe Cad., Erguvan Sitesi, \\ C Blok, D: 10, Atalar, Kartal, \\ 34000 İstanbul, Turkey \\ E-mail: obirtahadir@hotmail.com

(arsing \\ Keywords: Macular edema; \\ retinal vein occlusion; \\ single-dose intravitreal \\ bevacizumab.
}

\begin{abstract}
Objective: The aim of the present study was to investigate changes in short-term visual acuity and foveal thickness after single-dose intravitreal bevacizumab treatments for macular edema secondary to central retinal vein occlusion (CRVO) and branch retinal vein occlusion (BRVO).

Methods: The patients were separated into 2 groups: 18 eyes of 18 patients with BRVO, and 10 eyes of 10 patients with CRVO. Early Treatment Diabetic Retinopathy Study (ETDRS) visual acuity scores, changes in foveal thickness measured with optical coherence tomography, and complications of treatment were evaluated.

Results: In each monthly measurement, in the BRVO group, foveal thickness decreased from baseline statistically significantly from baseline $(p<0.05)$ and ETDRS score of visual acuity increase also was statistically significant $(p<0.05)$ at each interval. In the CVRO group, although I month after injection, foveal thickness decreased significantly $(p<0.05)$, and second and third months, the reduction in foveal thickness was not statistically significant $(p>0.05)$ and compared with preinjection values, increase ETDRS score at all months was not statistically significant $(p>0.05)$.
\end{abstract}

Conclusion: Treatment of macular edema secondary to BRVO with intravitreal injection of bevacizumab in the early stages was effective and reliable.

\section{INTRODUCTION}

In cases of branch retinal vein occlusion (BRVO), and central retinal vein occlusion (CRVO), the most predominant cause of visual impairment is macular edema. Laser photocoagulation and intravitreal drug applications have been investigated in the treatment of macular edema associated with retinal vein occlusion (RVO).

In both BRVO and CRVO, the intraocular level of vascular endothelial growth factor (VEGF) increases. ${ }^{[1]}$ One study reported that CRVO treated with intravitreal bevacizumab injection administered every 6 weeks for 6 months resulted in a decrease in macular edema and an increase in the level of visual acuity. ${ }^{[2]}$ Based on these results, the effectiveness of intravitreal bevacizumab injections for macular edema that developed as an outcome of BRVO was studied, and it was used as a treatment alternative. ${ }^{[3]}$ The effectiveness of other anti-VEGFs (ranibizumab and afflibercept) in the treatment of macular edema as a result of both CRVO and BRVO has also been demonstrated in many studies. ${ }^{[-7]}$

This study of patients with macular edema was an evaluation of changes in visual acuity and foveal thickness after treatment with single-dose intravitreal bevacizumab injections at monthly intervals for a period of 3 months and an assessment of complications arising from the therapy. 


\section{MATERIAL AND METHODS}

A total of 28 eyes of 28 patients who presented at the clinic between January 2012 and February 2015 and who received intravitreal bevacizumab (Avastin; Genentech Inc., South San Francisco, CA, USA) injections for the treatment of macular edema that developed as an outcome of BRVO or CRVO were retrospectively reviewed. Optical coherence tomography (OCT) (spectral domain OCT/SLO; OTI-OPKO Health Inc., Miami, FL, USA) measurements taken before treatment and I, 2, and 3 months after injections to eyes with BRVO or CRVO with were included in the research.

Other inclusion criteria were detection of macular edema secondary to BRVO or CRVO during ophthalmoscopic evaluation, foveal thickness $>250 \mu \mathrm{m}$ measured during OCT analysis, initial visual acuity based on Early Treatment Diabetic Retinopathy Study (ETDRS) chart score (Snellen equivalent) of $\leq 75$ (20/32). Patients with another organic eye disease that might induce a decrease in visual acuity were not included in the study. The patients were informed about possible complications of intraocular injection, and provided written, informed consent. A comprehensive ophthalmologic evaluation was performed before administering an injection, and at first, second, and third months, after the injection was given. The best corrected visual acuity was evaluated using the ETDRS scale. The anterior segment was examined using slit lamp biomicroscopy, and fundus examination was performed with indirect ophthalmoscopy. Intraocular pressure was measured and recorded with a Goldmann applanation tonometer. The presence of foveal ischemia before injection was evaluated using fundus fluorescein angiography. Foveal thickness was measured using spectral domain OCT. The thickness of I $\mathrm{mm}$ of central fovea was determined using the fast retinal map program each month for a period of 3 months.

Intravitreal bevacizumab was injected into 28 eyes of 28 patients with RVO and macular edema observed on first examination. Injections were performed in the operating room in compliance with sepsis-antisepsis protocol. After achievement of topical anesthesia with $0.5 \%$ proparacaine, the eye was irrigated with $5 \%$ povidone iodine. A $30-G$ needle was inserted through the pars plana 3.5 to $4.0 \mathrm{~mm}$ from the limbus, avoiding the lens, on the horizontal meridian and with consideration for the axial length of the eye. The injection of $1.25 \mathrm{mg} / 0.05 \mathrm{~mL}$ bevacizumab was then delivered into the central vitreus. Ciprofloxacin eye drops were prescribed for use 5 times a day for 7 days after the injection for prophylactic purposes.

Sociodemographic and disease-related data of the patients are provided in Table I.

Table I. Characteristics of 28 eyes of 28 patients who underwent intravitreal bevacizumab injection for the treatment of macular edema secondary to branch retinal vein and central retinal vein occlusion

\begin{tabular}{|c|c|}
\hline Branch retinal vein occlusion & Central retinal vein occlusion \\
\hline Gender & Gender \\
\hline II women & 4 women \\
\hline 7 men & 6 men \\
\hline Age (years) & Age (years) \\
\hline $58.66 \pm 8.45$ & $58.50 \pm 10.25$ \\
\hline Site of occlusion & Site of occlusion \\
\hline 12 eyes, superior temporal vein & I0 eyes, central retinal vein \\
\hline \multicolumn{2}{|l|}{6 eyes, inferior temporal vein } \\
\hline State of the lens & State of the lens \\
\hline 14 phakic eyes & 7 phakic eyes \\
\hline 4 pseudophakic eyes & 3 pseudophakic eyes \\
\hline Baseline foveal thickness $(\mu \mathrm{m})^{*}$ & Baseline foveal thickness $(\mu \mathrm{m})^{*}$ \\
\hline $425.26 \pm 70.14$ & $4|5.7| \pm 66.08$ \\
\hline Baseline Early Treatment Diabetic Retinopathy Study & Baseline Early Treatment Diabetic Retinopathy Study \\
\hline Visual Acuity (Snellen)* & Visual Acuity (Snellen)* \\
\hline $63.61 \pm 19.42$ & $33.14 \pm 6.09$ \\
\hline Disease onset - injection (days) & Disease onset - injection (days) ${ }^{*}$ \\
\hline $20.16 \pm 25.63$ (median: 10) & $18.12 \pm 26.34$ (median: 9) \\
\hline
\end{tabular}

"Mean \pm Standard deviatior. 
The cases were divided into 2 groups: macular edema secondary to BRVO and to CRVO. In the BRVO group, 18 eyes of 18 patients were included. These patients had either superior temporal $(n=12 ; 66.6 \%)$ or inferior temporal vein $(n=6 ; 33.3 \%)$ occlusion. There were 10 eyes of 10 patients in the CRVO group. Among all 28 cases, the concomitant diseases of hypertension ( $n=15 ; 53.57 \%)$, bleeding diathesis $(n=4 ; 14.28 \%)$, type 2 diabetes mellitus $(n=3$; $10.71 \%)$, heart failure $(n=2 ; 7.14 \%)$, hypothyroidism $(n=1$; $3.57 \%)$, hypercholesterolemia $(n=I ; 3.57 \%)$, autosomal dominant drusen $((\mathrm{n}=\mathrm{I} ; 3.57 \%)$, and macular degeneration secondary to dry eye $(n=I ; 3.57 \%)$ were detected. The mean time interval between the onset of the disease and the first injection was $19.39 \pm 25.4$ I days (median: 10 days).

The following parameters were investigated: the best corrected visual acuity, changes in foveal thickness determined using spectral domain OCT, and complications related to the intravitreal injections. SPSS Statistics for Windows, Version 17.0 (SPSS Inc., Chicago, IL, USA) was used for the statistical evaluation of findings. The data were analyzed using paired samples t-test, and $p<0.05$ was accepted as the level of statistical significance for intergroup differences.

\section{RESULTS}

The mean age of the 28 patients (female: $n=15 ; 53.57 \%$ and male: $n=13 ; 46.44 \%$ ) was $58.60 \pm 8.94$ years (range: 43 80 years). The mean time interval from disease onset to injection was 19.39 \pm 25.4 I days (median: 10 days).

Independent samples t-test analysis of the demographic data did not reveal a statistically significant difference between the 2 groups based on age $(p=0.96)$, gender $(p=0.3 \mathrm{I})$, time interval from disease onset to injection $(p=0.83)$, or baseline foveal thickness $(p=0.91)$.

The mean foveal thickness measured with OCT before and after monthly intravitreal bevacizumab injections is provided in Table 2. In the BRVO group, the mean ( $\pm S D$ ) foveal thickness was $415.26 \pm 70.14 \mu \mathrm{m}$ before treatment, and
$270.55 \pm 43.52 \mu \mathrm{m}, 283.88 \pm 43.20 \mu \mathrm{m}$, and $322.77 \pm 52.97$ $\mu \mathrm{m}$ at $\mathrm{I}, 2$, and 3 months, respectively (Table 2 ). When compared with the baseline measurement, the decrease in foveal thickness at first and second months was substantial, and statistically significant $(p<0.001)$. The smaller decrease in foveal thickness detected at third month was also statistically significant $(p<0.05)$.

In the CRVO group, the mean initial foveal thickness was $425.7 \mathrm{I} \pm 66.08 \mu \mathrm{m}$, and it was $36 \mathrm{I} .15 \pm 84.43 \mu \mathrm{m}$, $378.50 \pm 7 \mathrm{I} .34 \mu \mathrm{m}$, and $388.63 \pm 88.38 \mu \mathrm{m}$ at I, 2 , and 3 months after beginning treatment, respectively (Table 2). When compared with the pre-injection value, the decrease in foveal thickness at the first month was statistically significant $(p<0.05)$, while subsequent decreases in foveal thickness were not found to be statistically significant $(p>0.05)$.

The mean ETDRS letter chart scores (Snellen score equivalent) before, and 1,2, and 3 months after injections are shown in Table 3.

In the group with BRVO, the mean ETDRS score was $63.61 \pm 19.42(20 / 100)$ before treatment, and 83.05 \pm 10.15 (20/40), 8I.II $\pm 12.42(20 / 50)$, and $77.77 \pm 13.25$ (20/60) at postinjection first, second, and third months, respectively (Table 3). Based on the preinjection ETDRS score, the increase in visual acuity at months I and 2 was considerable, and statistically significant $(p<0.00 \mathrm{I})$. A smaller, but still statistically significant increase in visual acuity was detected at month $3(p<0.05)$.

In the CRVO group, the preliminary mean ETDRS score was 33. I $4 \pm 6.09$ (20/400), and mean score was $45.14 \pm$ I 6.64 (20/250), 4I.I $5 \pm 15.03(20 / 320)$, and 26.47 10.35 (20/500) at months I, 2, and 3, respectively (Table 3 ). When compared with the preinjection ETDRS score, the increase in visual acuity seen in subsequent months was not statistically significant $(\mathrm{p}>0.05)$.

During the follow-up period, no systemic side effects of bevacizumab were observed, and no ophthalmological complications were encountered.

Table 2. Mean foveal thickness before injection and I, 2, and 3 months after injection

\begin{tabular}{|c|c|}
\hline Branch retinal vein occlusion $(\mu \mathrm{m})(n=\mid 8)$ & Central retinal vein occlusion $(\mu \mathrm{m})(n=10)$ \\
\hline Preinjection: $425.26 \pm 70.14$ & Preinjection: $415.7 I \pm 66.08$ \\
\hline I ${ }^{\text {st }}$ month: $270.55 \pm 43.52$ & Ist month: $361.15 \pm 84.43$ \\
\hline $2^{\text {nd }}$ month: $283.88 \pm 48.20$ & 2nd month: $378.50 \pm 71.34$ \\
\hline $3^{\text {rd }}$ month: $322.77 \pm 52.97$ & 3rd month: $388.63 \pm 68.38$ \\
\hline Postinjection $-\mathrm{I}^{\text {st }}$ month $\mathrm{p}=0.000 \mathrm{I}^{*}$ & Postinjection- $\left.\right|^{\text {st }}$ month $\mathrm{p}=0.04^{* *}$ \\
\hline Postinjection- $2^{\text {nd }}$ month $p=0.00 \mathrm{I}^{*}$ & Postinjection $-2^{\text {nd }}$ month $p=0.06$ \\
\hline Postinjection $-3^{\text {rd }}$ month $p=0.03^{* *}$ & Postinjection- $3^{\text {rd }}$ month $p=0.15$ \\
\hline
\end{tabular}

Paired t-test ${ }^{*} \mathrm{p}<0.001 ;{ }^{* 0 *} \mathrm{p}<0.05$ 
Table 3. Mean ETDRS visual acuity score before injection and $\mathrm{I}, 2$, and 3 months after injection

\begin{tabular}{|c|c|}
\hline Branch retinal vein occlusion $(n=18)$ & Central retinal vein occlusion $(n=10)$ \\
\hline Preinjection: $63.61 \pm 19.42(20 / 100)$ letters & Preinjection: $33.14 \pm 6.09(20 / 400)$ letters \\
\hline$I^{\text {st }}$ month: $83.05 \pm 10.15(20 / 40)$ letters & $\left.\right|^{\text {st }}$ month: $45.14 \pm \mid 6.64(20 / 250)$ letters \\
\hline $2^{\text {nd }}$ month: $81 . I I \pm 12.42(20 / 50)$ letters & $2^{\text {nd }}$ month: $4 I .15 \pm 15.03(20 / 320)$ letters \\
\hline $3^{\text {rd }}$ month: $77.77 \pm 13.25(20 / 60)$ letters & $3^{\text {rd }}$ month: $26.47 \pm 10.35(20 / 500)$ letters \\
\hline Postinjection- $\mathrm{I}^{\text {st }}$ month $\mathrm{p}=0.000 \mathrm{I}^{* *}$ & Postinjection- $\mathrm{I}^{\mathrm{st}}$ month $\mathrm{p}=0.07$ \\
\hline Postinjection- $2^{\text {nd }}$ month $p=0.00 I^{* *}$ & Postinjection $-2^{\text {nd }}$ month $p=0.08$ \\
\hline Postinjection- $3^{\text {rd }}$ month $p=0.03^{*}$ & Postinjection $-3^{\text {rd }}$ month $p=0.52$ \\
\hline
\end{tabular}

Paired t-test " $p<0.05 ; "$ " $p<0.001$. ETDRS: Early Treatment Diabetic Retinopathy Study (Snellen equivalent).

\section{DISCUSSION}

RVO is a frequently seen disease of the retinal vasculature, second only to diabetic retinopathy. Though RVO has been defined as a single disease group, CRVO and BRVO differ in pathogenesis and treatment response. Macular edema is the predominant cause of visual impairment in both CRVO and BRVO. In RVO, interruption of blood circulation and a disruption of the blood-retina barrier lead to plasma exudation and subsequent macular edema. Treatment modalities targeting both pathogenetic factors and the formation of edema have been investigated. Although hemodilution therapy has been proposed as a treatment approach that would restore retinal blood flow to normal level, successful outcomes have not yet been achieved. ${ }^{[8]}$ Laser therapy and various intravitreal injections have also been studied.

Since macular edema can lead to irreversible photoreceptor damage, which may develop within just 3 months, it should be treated at an early stage of the disease. ${ }^{[9]}$ In our study, we administered intravitreal single-dose bevacizumab injections over the first 3 months of disease in order to prevent photoreceptor injury, to assess shortterm progression of venous occlusion in both groups, and to evaluate the need for additional early-stage treatment, such as laser photocoagulation.

Prognosis of visual acuity outcome is largely dependent on initial acuity. In cases with non-ischemic CRVO, without treatment, fewer than $10 \%$ of patients will recover normal visual acuity. ${ }^{[10]}$ The Central Vein Occlusion Study (CVOS) group demonstrated that baseline visual acuity is an important marker in the prediction of final degree of visual acuity, and is associated with presence of retinal perfusion. ${ }^{\left[{ }^{\prime \prime}\right]}$ For example it has been demonstrated that $65 \%$ of the patients who had baseline visual acuity of $\geq 20 / 40$ preserved this good level of visual acuity, and $80 \%$ of the cases with visual acuity of $\leq 20 / 200$ retained poor visual acuity. The outcomes of the CVOS study group also indicated that follow-up intervals should be determined based on initial visual acuity and the presence of ischemia. ${ }^{[7,11]}$ The
CVOS study and others have demonstrated that the use of new anti-VEGF agents and intravitreal steroid applications has achieved improved treatment results. ${ }^{[1,3,7,11-13]}$

Focal laser therapy for macular edema is not recommended in CRVO in the CVOS study, as the grid-like laser treatment applied to the macular area did not provide a positive effect on final visual acuity. ${ }^{[14]}$

In our study, the therapeutic effects of intravitreal 1.25 $\mathrm{mg}$ bevacizumab injection on visual acuity and foveal thickness in 28 cases with macular edema that developed as an outcome of BRVO or CRVO were investigated. In the BRVO group, when compared with preinjection values, a statistically significant decrease in foveal thickness was seen at $\mathrm{I}$ and 2 months after initial injection $(p<0.0 \mathrm{I})$ while at third month, a smaller, but still statistically significant, decrease was observed $(p<0.05)$. In the CRVO group, when compared with preinjection measurements, a statistically significant decrease in foveal thickness was seen at the first month $(p<0.05)$. Decreases at second and third months were not statistically significant $(p>0.05)$. In the BRVO group, an increase in ETDRS score was determined at months $I$ and 2 after treatment, which were statistically significant relative to preinjection score $(p<0.0 \mathrm{I})$, while smaller statistically significant increase $(p<0.05)$ was recorded at the third month. In the CRVO group, relative to preinjection value, the increase in ETDRS score was not statistically significant $(p>0.05)$ at any interval. Single-dose intravitreal bevacizumab injections decreased macular edema in cases with BRVO for three consecutive months, retinal thickness was maintained within normal limits, and statistically significant increases in visual acuity were observed. In CRVO patients, a statistically significant decrease in macular edema was observed at I month after injection; however, intravitreal bevacizumab gradually lost its therapeutic effect beginning at month 2 , and at final post-treatment evaluation, no statistically significant increase in visual acuity was achieved.

Stahl et al. suggested that the appropriate anatomical and 
functional vascularization process may take a very long time in cases of RVO, and that circulation can be maintained with collateral vascular vessels. Therefore, they asserted that bevacizumab treatment should be continued until appropriate retinal circulation was achieved. ${ }^{[15]}$ Based on our results, however, we would suggest that, particularly in cases with CRVO, single-dose bevacizumab monotherapy may fail to have adequate therapeutic effect.

We detected no ophthalmological complications related to intravitreal bevacizumab injections. A lack of any change in electrophysiological values after intravitreal bevacizum$\mathrm{ab}$ injections in cases of RVO has been demonstrated. ${ }^{[16]}$ In that study, single-dose intravitreal bevacizumab injections were administered for 9 CRVO and 12 BRVO eyes with macular edema, and the patients were followed up for 12 weeks. No sign of ocular toxicity was observed at the conclusion of the research. The present study was designed to evaluate the early course of disease in these 2 groups, and to assess the need for recurrent injections at an early stage.

One of the limitations of our study is the small number of participants. In addition, it was not prospective in nature, and there was no control group. Furthermore, bevacizum$\mathrm{ab}$ is not licensed for intravitreal use.

A statistically significant increase in visual acuity seen I month after intravitreal bevacizumab injection was maintained through the third month in the BRVO group; however, a similar effect was not seen in the CRVO group. Though a statistically significant decrease in foveal thickness was obtained in the CRVO group when compared with pre-injection values, which indicated achievement of some functional and anatomical improvement, the same degree of improvement as in the BRVO group was not observed, suggesting the presence of greater damage in the CRVO group. In conclusion, treatment of macular edema that had developed as a result of RVO using intravitreal bevacizumab injections in the early phase had successful results. However, we think that a full evaluation of results on this topic requires larger, prospective studies.

Ethics Committee Approval

The approval of the local Ethics Committee was obtained. Informed Consent

Approval was obtained from the patients.

Peer-review

Internally peer-reviewed.

Authorship Contributions

Concept: T.A., A.Y.A.O., Ü.Ç., B.K. O.Ş., Y.Ö.; Design: T.A., A.Y.A.O., Ü.Ç., B.K., O.Ş., Y.Ö.; Data collection \&/or processing: T.A.; Analysis and/or interpretation: T.A., A.Y.A.O., Ü.Ç., B.K., O.Ş.; Literature search: T.A., A.Y.A.O., Ü.Ç., B.K.; Writing: T.A.; Critical review: T.A., A.Y.A.O., Ü.Ç., B.K., O.Ş., Y.Ö.
Conflict of Interest

None declared.

\section{REFERENCES}

1. Boyd SR, Zachary I, Chakravarthy U, Allen GJ, Wisdom GB, Cree IA, et al. Correlation of increased vascular endothelial growth factor with neovascularization and permeability in ischemic central vein occlusion. Arch Ophthalmol 2002;120:1644-50. [CrossRef]

2. Epstein DL, Algvere PV, von Wendt G, Seregard S, Kvanta A. Bevacizumab for macular edema in central retinal vein occlusion: a prospective, randomized, double-masked clinical study. Ophthalmology 2012;119:1184-9. [CrossRef]

3. Ehlers JP, Decroos FC, Fekrat S. Intravitreal bevacizumab for macular edema secondary to branch retinal vein occlusion. Retina 2011;31:1856-62. [CrossRef]

4. Brown DM, Campochiaro PA, Bhisitkul RB, Ho AC, Gray S, Saroj $\mathrm{N}$, et al. Sustained benefits from ranibizumab for macular edema following branch retinal vein occlusion: 12 -month outcomes of a phase III study. Ophthalmology 2011;118:1594-602. [CrossRef]

5. Campochiaro PA, Brown DM, Awh CC, Lee SY, Gray S, Saroj N, et al. Sustained benefits from ranibizumab for macular edema following central retinal vein occlusion: twelve-month outcomes of a phase III study. Ophthalmology 2011;118:2041-9. [CrossRef]

6. Brown DM, Heier JS, Clark WL, Boyer DS, Vitti R, Berliner AJ, et al. Intravitreal aflibercept injection for macular edema secondary to central retinal vein occlusion: 1-year results from the phase $3 \mathrm{CO}$ PERNICUS study. Am J Ophthalmol 2013;155:429-37.e7.

7. Heier JS, Campochiaro PA, Yau L, Li Z, Saroj N, Rubio RG, et al. Ranibizumab for macular edema due to retinal vein occlusions: long-term follow-up in the HORIZON trial. Ophthalmology 2012;119:802-9. [CrossRef]

8. Chen HC, Wiek J, Gupta A, Luckie A, Kohner EM. Effect of isovolaemic haemodilution on visual outcome in branch retinal vein occlusion. Br J Ophthalmol 1998;82:162-7. [CrossRef]

9. Bavbek T, Yenice O, Toygar O. Problems with attempted chorioretinal venous anastomosis by laser for nonischemic CRVO and BRVO. Ophthalmologica 2005;219:267-71. [CrossRef]

10. Quinlan PM, Elman MJ, Bhatt AK, Mardesich P, Enger C. The natural course of central retinal vein occlusion. Am J Ophthalmol 1990;110:118-23. [CrossRef]

11. Natural history and clinical management of central retinal vein occlusion. The Central Vein Occlusion Study Group. Arch Ophthalmol 1997;115:486-91. [CrossRef]

12. Ip MS, Scott IU, VanVeldhuisen PC, Oden NL, Blodi BA, Fisher M, et al; SCORE Study Research Group. A randomized trial comparing the efficacy and safety of intravitreal triamcinolone with observation to treat vision loss associated with macular edema secondary to central retinal vein occlusion: the Standard Care vs Corticosteroid for Retinal Vein Occlusion (SCORE) study report 5. Arch Ophthalmol 2009;127:1101-14. [CrossRef]

13. Haller JA, Bandello F, Belfort R Jr, Blumenkranz MS, Gillies M, Heier J, et al. Dexamethasone intravitreal implant in patients with macular edema related to branch or central retinal vein occlusion twelve-month study results. Ophthalmology 2011;118:2453-60.

14. Evaluation of grid pattern photocoagulation for macular edema in central vein occlusion. The Central Vein Occlusion Study Group M 
report. Ophthalmology 1995;102:1425-33. [CrossRef]

15. Stahl A, Agostini H, Hansen LL, Feltgen N. Bevacizumab in retinal vein occlusion-results of a prospective case series. Graefes Arch Clin Exp Ophthalmol 2007;245:1429-36. [CrossRef]
16. Pai SA, Shetty R, Vijayan PB, Venkatasubramaniam G, Yadav NK, Shetty BK, et al. Clinical, anatomic, and electrophysiologic evaluation following intravitreal bevacizumab for macular edema in retinal vein occlusion. Am J Ophthalmol 2007;143:601-6. [CrossRef]

\section{Retina Ven Dal ve Santral Ven Tıkanıklığına Bağlı Maküla Ödemi Gelişen Gözlerde Tek Doz Intravitreal Bevacizumab Tedavisinin Kısa Dönem Sonuçları}

Amaç: Retina ven dal tıkanıklığı ve santral ven tıkanıklığına bağlı maküla ödemi tedavisinde tek doz intravitreal bevacizumab enjeksiyonu sonrası kısa dönem görme keskinliği ve fovea kalınlığı değişikliklerini incelemek.

Gereç ve Yöntem: Hastalar iki ayrı gruba ayrılıp ven dal tıkanıklığına grubuna 18 hastanın 18 gözü, santral ven tıkanıklığı grubuna 10 hastanın 10 gözü dahil edildi. Çalışmada araştırılan göstergeler Early Treatment Diabetic Retinopathy Study (ETDRS) görme keskinliği ve OCT ile ölçülen fovea kalınlığı değişiklikleri ve komplikasyonlar idi.

Bulgular: Retinal ven dal tıkanıklığı grubunda tüm aylarda başlangıca göre fovea kalınlığında görülen azalma istatistiksel olarak anlamlı bulundu $(p<0.05)$ ve ortalama ETDRS harf değerinde (Snellen eşdeğeri) enjeksiyon sonrası tüm aylarda görme keskinliğinde görülen artış istatistiksel olarak anlamlı bulundu $(p<0.05)$. Santral ven tıkanıklığı grubunda enjeksiyon öncesi birinci ayda başlangıca göre fovea kalınlığında görülen azalma istatistiksel olarak anlamlı $(p<0.05)$ iken ikinci ve üçüncü aylardaki azalma miktarı istatistiki olarak anlamlı düzeyde değildi $(p>0.05)$ ve ortalama ETDRS harf değerinde Enjeksiyon öncesi ETDRS harf değerine göre enjeksiyon sonrası tüm aylarda görme keskinliğinde görülen artış istatistiksel olarak anlamlı değildi $(p>0.05)$.

Sonuç: Retina ven dal tıkanıklığına bağı maküla ödemi tedavisinde intravitreal bevacizumab enjeksiyonunun erken dönemde etkili ve güvenilir olduğu düşünüldü.

Anahtar Sözcükler: Makuler ödem; retinal ven tıkanıklığ; tek doz intravitreal bevacizumab. 